International Journal of Instruction

e-ISSN: 1308-1470 • www.e-iji.net
July $2019 \bullet$ Vol.12, No.3

p-ISSN: 1694-609X

pp. 359-374

Received: 10/08/2018

Revision: 01/04/2019

Accepted: 09/04/2019

OnlineFirst:06/05/2019

\title{
Prospective Primary School Teachers' Conception Change on States of Matter and Their Changes through Predict-Observe-Explain Strategy
}

\author{
Anasufi Banawi \\ School of Postgraduate Studies, Universitas Pendidikan Indonesia, Indonesia Institut \\ Agama Islam Negeri Ambon, Indonesia, anasufibanawi@student.upi.edu
}

Wahyu Sopandi

Universitas Pendidikan Indonesia, Indonesia,wsopandi@upi.edu

\section{Asep Kadarohman}

Universitas Pendidikan Indonesia, Indonesia, kadar@upi.edu

\section{Solehuddin}

Universitas Pendidikan Indonesia, Indonesia, msolehuddin@upi.edu

\begin{abstract}
This preliminary study aims at developing a program to improve teacher candidate students' conceptions on the topic of states of matter and their changes by using Predict-Observe-Explain (POE) strategy. This study employs pre-experimental method. The subjects involved were third-semester students of a primary school teacher education study program (Pendidikan Guru Sekolah Dasar - PGSD) in a university in West Java, Academic Year 2017/2018. The research instrument was a five-tiered diagnostic test in the form of multiple-choice. The instrument had gone through expert and empirical validation processes, which were provided before and after the implementation of the POE strategy. The data obtained were analyzed through descriptive and inferential statistics (t-test). The results showed that the use of POE strategy was able to improve the students' comprehension on the concept of states of matter and their changes either at macroscopic level ( $\mathrm{N}$-gain $0.32, \mathrm{p}=0.00$ ), submicroscopic level (verbal $\mathrm{N}$-gain $0.44 ; \mathrm{p}=0.00$, and visual $\mathrm{N}$ gain $0.49 ; \mathrm{p}=0.00)$, or symbolic level $(\mathrm{N}$-gain $0.41 ; \mathrm{p}=0.00)$. The acquired $\mathrm{N}$-gain indicated the need for further research to improve the course program of states of matter and their changes using the POE strategy to obtain higher $\mathrm{N}$-gain that indicates the need for improvement of the program, including the processes and aids of the course.
\end{abstract}

Keywords: conception change, states of matter and their changes, POE strategy, prospective teachers, primary school

Citation: Banawi, A., Sopandi, W., Kadarohman, A., \& Solehuddin, M. (2019). Prospective Primary School Teachers' Conception Change on States of Matter and Their Changes through Predict-ObserveExplain Strategy. International Journal of Instruction, 12(3), 359-374. https://doi.org/10.29333/iji.2019.12322a 


\section{INTRODUCTION}

In order for students to have a good comprehension of objects, substances, and particles, teachers must first understand and be able to teach the topic or concept well and properly. This is in line with Sanjaya (2009), who mentions that teacher becomes a key factor in developing students' thinking skills in schools without disregarding other factors such as textbooks and other teaching aids (Lating, 2014; Karagöl \& Bekmezci, 2015), and learning attitudes and interests.

POE stands for Predict, Observe, and Explain. POE was first developed by White and Gunstone (1992) (Mancuso, 2010, p. 4; Cinici \& Demir, 2013). POE is a "strategy" that actively involves students in demonstrations by predicting what will happen before the experiment, observing, and finally trying to explain it, verbally and or in writing (Mancuso, 2010).

There has been prior research on the comprehension of the concepts of science in primary schools (See Jaelani, 2015) and the prospective teachers' comprehension on the concept of states of matter and their changes (See Sopandi et al, 2017; Banawi et al., 2017). In addition, there are several articles related to the use of Predict-ObserveExplain (POE) strategies in learning (See Liew \&Treagust, 2004; Joyce, 2006; Keles \& Demirel, 2010; Ipek et al., 2010; Cos su et al, 2012; Cinici \& Demir, 2013; Gernale et al, 2015; Hilario, 2015). However, the use of the POE strategy for the purpose of improving the mastery of the topic "States of Matter and Their Changes" has never been mentioned, especially investigations on the use of POE strategies on the prospective primary school teachers' comprehension on the topic, including an analysis of the overall pattern of change at the macroscopic, submicroscopic, and symbolic levels, and the direction of its effectiveness.

The weakness of teachers and prospective teachers needs to be found a solution. This can be done by applying proper learning models in primary school. Giving lectures about those models becomes a provision for prospective teachers to teach it to future students. One of the strategies that can be applied is Predict-Observe Explain (POE). As a response, this study employs the POE strategy with learning aids for the states of matter and their changes topic that have been developed previously.

Regarding representation, Johnstone (1982) distinguishes three levels of "material" representation into macroscopic, submicroscopic and symbolic levels. There is a difference in understanding the sub-micro-level level of verbal and visual aspects (Sopandi, Latip \& Sujana, 2017). The existence of these differences raises the need to identify these levels into two categories as the information about students' understanding. In addition to the importance of understanding at each level, students must also be able to connect from one level to another because these representations are complementary (Johnstone, 2000; Treagust, Chittleborough \& Mamiala, 2003; Li \& Arshad, 2014). 
Referring to the background, the issue raised in this study focused on the question "how is the conceptual change of prospective primary school teachers on the topic of states of matter and their changes using POE strategy?" The concept changes discussed in this study are conceptual changes after learning with POE strategy. Mastery of the topic of prospective primary school teachers includes their understanding at macroscopic, submicroscopic (verbal and visual), and symbolic levels. The results of this study enrich the data of prospective primary school teachers' conception of the above topic, hence they becomes the inspiration to take corrective action and further research.

\section{METHOD}

\section{Research Method}

This study employs pre-experimental method (one class) with a one-group pre-test posttest design (Sugiyono, 2013, p. 415; Creswell, 2016, p. 241), as shown in Figure 1 below.

Experimental Group (A)

$: \mathrm{O}_{1}$

$\chi_{1}$

$\mathrm{O}_{2}$

Figure 1. Pre-Experimental Design

The class was assigned as a pretest, followed by lecture on the topic of states of matter and their changes using POE strategy, and final test (posttest). The pretest and the posttest items were the same.

\section{Subjects}

The subjects were 45 third-semester teacher candidate students in a Primary School Teacher Education (PGSD/Pendidikan Guru Sekolah Dasar) Study Program in one of universities West Java, 2017/2018 Academic Year, consisting of 34 female and 11 male students.They have taken lectures on Basic Concepts of Science, Primary School Science Instruction, and Primary School Science Practice.

\section{Data Collection Instrument}

This study used a five-tiered diagnostic test in the form of multiple-choices. The instrument tested the students' comprehension on the topic of states of matter and their changes, which was divided into subtopics of discontinuity of matter, dynamic property of particles, the nature of particles substance, and changes in states. The instrument had gone through expert and empirical validation processes, which were performed by three experts: a chemistry education expert, a chemist, and a primary school education expert to examine the suitability of the item with the content of the topic (Sugiyono, 2013, p. 177). The instrument was revised based on the results of experts' validation, then empirical validation was done to test its reliability (r) and it gained $r=0.774$.

The trial was conducted on 53 prospective teacher students at one of the universities in Maluku. Test analysis was carried out at only four stages (macroscopic, verbal submicroscopic, visual submicroscopic, symbolic levels) not at the level of confidence in the choice of answers according to the existing theory. The questions used are 17 questions with 68 items (obtained from 17 times 4). Identification of misconceptions shows that how to overcome misconceptions and not understand concepts is very 
different (Hasan, Bagayoko \& Kelley, 1999; Hakim, Liliasari, \& Kadarohman, 2012). Thus, the score for the respondent's answer is related to the level of answer confidence or Certainty Response Index (CRI). Giving a score for CRI $>2.5$ or CRI $<2.5$ in the opinion of researchers should also be different. Therefore, two additional groupings of understanding are proposed, namely (1) for respondents whose partially correct answers (some incorrect answers) with CRI> 2.5 are grouped in 'partial understanding' and (2) respondents who have some correct answers (some answers are wrong) with CRI <2.5 grouped in 'partial misconception'. The choice of answers for each item correctly with CRI $>2.5$ is given a score of 2; The choice of answers for each item correctly with CRI $<2.5$ is given a score of 1 ; The choice of answer for each item is wrong with CRI $<2.5$ given a score of 0 ; The choice of answer for each item incorrectly with CRI> 2.5 is given a score of -1 .Furthermore,the scoring for the test results followed a combination of answers developed by Banawi et al. (2018). The combination of answers is presented in Table 1.

Table 1

Combination of Answers in the Five-tiered Diagnostic Test

\begin{tabular}{|c|c|c|c|c|c|c|c|}
\hline \multirow[b]{2}{*}{ No. } & \multirow[b]{2}{*}{ Category } & \multicolumn{5}{|c|}{ Combination of answers } & \multirow[b]{2}{*}{ Score } \\
\hline & & $\begin{array}{l}\text { Macros } \\
\text { scopic }\end{array}$ & $\begin{array}{l}\text { Verbal Sub- } \\
\text { microscopic }\end{array}$ & $\begin{array}{l}\text { Visual Sub- } \\
\text { microscopic }\end{array}$ & Symbolic & $\begin{array}{l}\text { CRI } \\
\text { Value }\end{array}$ & \\
\hline 1 & $\mathrm{CC}$ & Correct & Correct & Correct & Correct & $>2.5$ & 8 \\
\hline \multirow[t]{20}{*}{2} & PC & Correct & Correct & Correct & Incorrect & $>2.5$ & 5 \\
\hline & $\mathrm{PC}$ & Correct & Correct & Incorrect & Correct & $>2.5$ & 5 \\
\hline & $\mathrm{PC}$ & Correct & Incorrect & Correct & Correct & $>2.5$ & 5 \\
\hline & PC & Incorrect & Correct & Correct & Correct & $>2.5$ & 5 \\
\hline & $\mathrm{PC}$ & Correct & Correct & Correct & Incorrect & $<2.5$ & 3 \\
\hline & $\mathrm{PC}$ & Correct & Correct & Incorrect & Correct & $<2.5$ & 3 \\
\hline & $\mathrm{PC}$ & Correct & Incorrect & Correct & Correct & $<2.5$ & 3 \\
\hline & $\mathrm{PC}$ & Incorrect & Correct & Correct & Correct & $<2.5$ & 3 \\
\hline & $\mathrm{PC}$ & Correct & Correct & Incorrect & Incorrect & $>2.5$ & 2 \\
\hline & $\mathrm{PC}$ & Correct & Incorrect & Incorrect & Correct & $>2.5$ & 2 \\
\hline & $\mathrm{PC}$ & Incorrect & Incorrect & Correct & Correct & $>2.5$ & 2 \\
\hline & $\mathrm{PC}$ & Correct & Incorrect & Correct & Incorrect & $>2.5$ & 2 \\
\hline & $\mathrm{PC}$ & Correct & Correct & Incorrect & Incorrect & $<2.5$ & 2 \\
\hline & $\mathrm{PC}$ & Correct & Incorrect & Incorrect & Correct & $<2.5$ & 2 \\
\hline & $\mathrm{PC}$ & Correct & Incorrect & Correct & Incorrect & $<2.5$ & 2 \\
\hline & PC & Incorrect & Incorrect & Correct & Correct & $<2.5$ & 2 \\
\hline & $\mathrm{PC}$ & Correct & Incorrect & Incorrect & Incorrect & $<2.5$ & 1 \\
\hline & PM & Incorrect & Incorrect & Incorrect & Correct & $<2.5$ & 1 \\
\hline & PM & Incorrect & Correct & Incorrect & Incorrect & $<2.5$ & 1 \\
\hline & PM & Incorrect & Incorrect & Correct & Incorrect & $<2.5$ & 1 \\
\hline \multirow[t]{4}{*}{3} & PM & Correct & Incorrect & Incorrect & Incorrect & $>2.5$ & -1 \\
\hline & PM & Incorrect & Incorrect & Incorrect & Correct & $>2.5$ & -1 \\
\hline & PM & Incorrect & Correct & Incorrect & Incorrect & $>2.5$ & -1 \\
\hline & PM & Incorrect & Incorrect & Correct & Incorrect & $>2.5$ & -1 \\
\hline 4 & $\mathrm{M}$ & Incorrect & Incorrect & Incorrect & Incorrect & $>2.5$ & -4 \\
\hline 5 & $\mathrm{NC}$ & Correct & Correct & Correct & Correct & $<2.5$ & 4 \\
\hline 6 & $\mathrm{E}$ & Incorrect & Incorrect & Incorrect & Incorrect & $<2.5$ & 0 \\
\hline
\end{tabular}


Lectures by lecturers using the POE strategy were held in 4 meetings from September 20, 2017 to October 11, 2017.

\section{Data Analysis}

All answers obtained from 45 subjects were typed in MS-Excel Program, grouped, and scored according to the guide in Table 1. Furthermore, the data obtained were analyzed descriptively using percentage.

The normalized gain ( $N$-gain) developed by Meltzer (2002) was used to calculate the magnitude of the prospective primary school teachers' concept comprehension based on the pretest and posttest values. The formula is presented as follows:

Normalized gain $=\frac{\text { posttestscore-pretestscore }}{\text { maximumpossiblescore-pretestscore }}$

Next, the $N$-gain calculation results were confirmed according to classification in Table 2 .

Table 2

Criteria of $N$-gain

\begin{tabular}{ll}
\hline $\mathrm{N}$-gain $(<\mathrm{g}>)$ & Classification \\
\hline $\mathrm{g} \geq 0.70$ & High \\
$0.30 \leq \mathrm{g}<0.70$ & Medium \\
$\mathrm{g}<0.30$ & Low \\
\hline
\end{tabular}

To establish the pattern of conceptual changes that occurred in the prospective teachers' comprehension, their answers were grouped based on their conceptual change patterns of each category of pretest and posttest answers. The statistical analysis were the paired sample t-test and Wilcoxon-test (with $\alpha=0.05$ ) using SPSS version 20.0 for Windows. The analysis was directed toward a comparison of pretest and posttest. Requirements for paired sample t-test are: (1) the difference between the two data is normal distribution. If the difference is not normal distribution, the different test is done by non-parametric test (Wilcoxon test) and (2) dependent variable ratio / interval.

\section{FINDINGS}

The results are summarized in the following tables. 
Table 3

Pretest, Posttest, and N-gain Scores of Prospective Primary School Teachers

\begin{tabular}{|c|c|c|c|c|c|c|c|}
\hline \multirow{2}{*}{$\begin{array}{l}\text { Prospective } \\
\text { Teachers }\end{array}$} & \multicolumn{3}{|l|}{ Score } & \multirow{2}{*}{$\begin{array}{l}\text { Prospective } \\
\text { Teachers }\end{array}$} & \multicolumn{3}{|l|}{ Score } \\
\hline & Pretest & Posttest & $N$-gain & & Pretest & Posttest & $N$-gain \\
\hline 1 & 47.79 & 66.91 & 0.37 & 24 & 60.29 & 69.12 & 0.22 \\
\hline 2 & 58.09 & 9.56 & -1.16 & 25 & 36.03 & 55.88 & 0.31 \\
\hline 3 & 60.29 & 82.35 & 0.56 & 26 & 55.15 & 52.94 & -0.05 \\
\hline 4 & 69.12 & 81.62 & 0.40 & 27 & 61.76 & 61.76 & 0.00 \\
\hline 5 & 39.71 & 71.32 & 0.52 & 28 & 36.03 & 73.53 & 0.59 \\
\hline 6 & 37.50 & 50.00 & 0.20 & 29 & 52.21 & 62.50 & 0.22 \\
\hline 7 & 75.74 & 84.56 & 0.36 & 30 & 36.76 & 71.32 & 0.55 \\
\hline 8 & 58.09 & 64.71 & 0.16 & 31 & 19.12 & 62.50 & 0.54 \\
\hline 9 & 70.59 & 82.35 & 0.40 & 32 & 53.68 & 71.32 & 0.38 \\
\hline 10 & 38.97 & 82.35 & 0.71 & 33 & 40.44 & 69.12 & 0.48 \\
\hline 11 & 56.62 & 82.35 & 0.59 & 34 & 50.74 & 72.06 & 0.43 \\
\hline 12 & 52.21 & 82.35 & 0.63 & 35 & 16.18 & 20.59 & 0.05 \\
\hline 13 & 47.06 & 73.53 & 0.50 & 36 & 31.62 & 72.06 & 0.59 \\
\hline 14 & 22.79 & 40.44 & 0.23 & 37 & 48.53 & 71.32 & 0.44 \\
\hline 15 & 43.38 & 75.74 & 0.57 & 38 & 75.74 & 88.97 & 0.55 \\
\hline 16 & 58.09 & 77.94 & 0.47 & 39 & 15.44 & 75.74 & 0.71 \\
\hline 17 & -1.47 & 51.47 & 0.52 & 40 & 31.62 & 84.56 & 0.77 \\
\hline 18 & 76.47 & 84.56 & 0.34 & 41 & 47.06 & 48.53 & 0.03 \\
\hline 19 & 66.91 & 86.76 & 0.60 & 42 & 40.44 & 66.91 & 0.44 \\
\hline 20 & 53.68 & 66.91 & 0.29 & 43 & 25.74 & 42.65 & 0.23 \\
\hline 21 & 66.91 & 86.03 & 0.58 & 44 & 44.85 & 75.74 & 0.56 \\
\hline 22 & 69.85 & 84.56 & 0.49 & 45 & 22.79 & 80.15 & 0.74 \\
\hline 23 & 27.94 & 88.97 & 0.85 & & & & \\
\hline Mean & & & & & 46.63 & 69.04 & 040 \\
\hline
\end{tabular}

Table 3 shows that the pretest mean was 46.63. This indicated that previous learning experiences had not adequately provided comprehension for the prospective primary school teachers to help their students learn about the topic of states of matter and their changes. Meanwhile, the posttest mean score showed that POE strategy could improve prospective teachers' comprehension of the topic. However, the increase was still in the medium category $(0.40)$. 
Table 4

Mean of Pretest, Posttest, and N-gain of Prospective Teachers in Macroscopic, Submicroscopic, and Symbolic, and Sub-materials

\begin{tabular}{|c|c|c|c|c|c|}
\hline \multirow{2}{*}{ Topic } & \multirow{2}{*}{ Level } & \multicolumn{4}{|c|}{ Score Mean } \\
\hline & & Pretest & Posttest & $N$-gain & Category \\
\hline \multirow{6}{*}{$\begin{array}{l}\text { Discontinuit } \\
\text { y of Matter }\end{array}$} & Macroscopic & 59.44 & 76.67 & 0.42 & Medium \\
\hline & Verbal submicroscopic & 60.00 & 79.44 & 0.49 & Medium \\
\hline & Visual submicroscopic & 67.78 & 84.44 & 0.52 & Medium \\
\hline & Symbolic & 59.44 & 72.78 & 0.33 & Medium \\
\hline & Score Mean & 61.67 & 78.33 & 0.43 & Medium \\
\hline & Final Score Mean & 42.99 & 67.36 & 0.43 & Medium \\
\hline \multirow{6}{*}{$\begin{array}{l}\text { Dynamic } \\
\text { Property of } \\
\text { Particles }\end{array}$} & Macroscopic & 73.89 & 69.44 & -0.17 & Low \\
\hline & Verbal submicroscopic & 75.56 & 84.44 & 0.36 & Medium \\
\hline & Visual submicroscopic & 63.33 & 78.33 & 0.41 & Medium \\
\hline & Symbolic & 38.33 & 50.56 & 0.20 & Low \\
\hline & Score Mean & 62.78 & 70.69 & 0.21 & Low \\
\hline & Final Score Mean & 44.17 & 55.90 & 0.21 & Low \\
\hline \multirow{6}{*}{$\begin{array}{l}\text { Nature of } \\
\text { Particle } \\
\text { Substance }\end{array}$} & Macroscopic & 78.52 & 89.63 & 0.52 & Medium \\
\hline & Verbal submicroscopic & 59.26 & 78.52 & 0.47 & Medium \\
\hline & Visual submicroscopic & 68.89 & 85.19 & 0.52 & Medium \\
\hline & Symbolic & 74.81 & 94.81 & 0.79 & High \\
\hline & Score Mean & 70.37 & 87.04 & 0.56 & Medium \\
\hline & Final Score Mean & 54.91 & 80.19 & 0.56 & Medium \\
\hline \multirow{6}{*}{$\begin{array}{l}\text { Changes of } \\
\text { States }\end{array}$} & Macroscopic & 85.93 & 94.44 & 0.60 & Medium \\
\hline & Verbal submicroscopic & 62.22 & 77.41 & 0.40 & Medium \\
\hline & Visual submicroscopic & 43.33 & 71.48 & 0.50 & Medium \\
\hline & Symbolic & 64.81 & 86.67 & 0.62 & Medium \\
\hline & Score Mean & 64.07 & 82.50 & 0.51 & Medium \\
\hline & Final Score Mean & 46.57 & 73.33 & 0.50 & Medium \\
\hline
\end{tabular}

Table 4 above shows that the POE strategy could improve the conceptual understanding of prospective primary school teachers at almost all levels. However, the increase was still in the medium category. Understanding the macroscopic level (for all questions and sub-material) had a greater percentage compared to the other levels (verbal submicroscopic, visual submicroscopic, and symbolic). On the other hand, understanding the symbolic level had a smaller percentage compared to the other levels. Based on the processed test (pretest and posttest) scores, a percentage of the prospective primary school teachers' comprehension was made based on the sub-material of states of matter and their changes as presented in Table 5. 
Table 5

Percentage of Prospective Primary School Teachers' Comprehension based on the Submaterials

\begin{tabular}{|c|c|c|c|c|c|c|c|c|c|c|c|c|c|}
\hline \multirow[t]{2}{*}{ Sub Topic } & & \multicolumn{6}{|c|}{ Pretest (\%) } & \multicolumn{6}{|c|}{ Posttest (\%) } \\
\hline & & $\mathrm{CC}$ & PC & PM & $\mathrm{NC}$ & $\mathrm{M}$ & $\bar{E}$ & $\mathrm{CC}$ & PC & PM & $\mathrm{NC}$ & $\mathrm{M}$ & E \\
\hline \multirow{4}{*}{$\begin{array}{l}\text { Discontinuity } \\
\text { of Matter }\end{array}$} & 1 & 17.78 & 73.33 & 6.67 & 2.22 & 0.00 & 0.00 & 66.67 & 28.89 & 0.00 & 2.22 & 2.22 & 0.00 \\
\hline & 2 & 4.44 & 68.89 & 17.78 & 2.22 & 6.67 & 0.00 & 2.22 & 66.67 & 22.22 & 0.00 & 6.67 & 2.22 \\
\hline & 3 & 44.44 & 44.44 & 6.67 & 2.22 & 2.22 & 0.00 & 82.22 & 8.89 & 8.89 & 0.00 & 0.00 & 0.00 \\
\hline & 4 & 15.56 & 48.89 & 26.67 & 0.00 & 6.67 & 2.22 & 51.11 & 46.67 & 2.22 & 0.00 & 0.00 & 0.00 \\
\hline Dynamic & 5 & 57.78 & 31.11 & 6.67 & 4.44 & 0.00 & 0.00 & 71.11 & 28.89 & 0.00 & 0.00 & 0.00 & 0.00 \\
\hline Property of & 6 & 13.33 & 55.56 & 22.22 & 2.22 & 6.67 & 0.00 & 40.00 & 51.11 & 6.67 & 0.00 & 2.22 & 0.00 \\
\hline \multirow[t]{2}{*}{ Particles } & 7 & 15.56 & 71.11 & 8.89 & 0.00 & 0.00 & 4.44 & 26.67 & 66.67 & 4.44 & 2.22 & 0.00 & 0.00 \\
\hline & 8 & 4.44 & 82.22 & 6.67 & 0.00 & 2.22 & 4.44 & 0.00 & 57.78 & 31.11 & 0.00 & 11.11 & 0.00 \\
\hline Nature of & 9 & 44.44 & 46.67 & 4.44 & 2.22 & 2.22 & 0.00 & 66.67 & 31.11 & 0.00 & 0.00 & 2.22 & 0.00 \\
\hline Particles & 10 & 15.56 & 66.67 & 13.33 & 0.00 & 4.44 & 0.00 & 62.22 & 33.33 & 2.22 & 0.00 & 2.22 & 0.00 \\
\hline Substance & 11 & 37.78 & 46.67 & 13.33 & 0.00 & 2.22 & 0.00 & 75.56 & 15.56 & 8.89 & 0.00 & 0.00 & 0.00 \\
\hline Changes of & 12 & 37.78 & 57.78 & 2.22 & 0.00 & 2.22 & 0.00 & 57.78 & 40.00 & 2.22 & 0.00 & 0.00 & 0.00 \\
\hline \multirow[t]{6}{*}{ States } & 13 & 40.00 & 53.33 & 4.44 & 0.00 & 0.00 & 2.22 & 66.67 & 31.11 & 2.22 & 0.00 & 0.00 & 0.00 \\
\hline & 14 & 11.11 & 84.44 & 2.22 & 0.00 & 2.22 & 0.00 & 37.78 & 60.00 & 0.00 & 0.00 & 2.22 & 0.00 \\
\hline & 15 & 11.11 & 68.89 & 20.00 & 0.00 & 0.00 & 0.00 & 53.33 & 40.00 & 6.67 & 0.00 & 0.00 & 0.00 \\
\hline & 16 & 15.56 & 66.67 & 13.33 & 0.00 & 2.22 & 2.22 & 51.11 & 44.44 & 4.44 & 0.00 & 0.00 & 0.00 \\
\hline & 17 & 8.89 & 60.00 & 22.22 & 0.00 & 6.67 & 2.22 & 48.89 & 40.00 & 4.44 & 4.44 & 0.00 & 2.22 \\
\hline & Mean & 23.27 & 60.39 & 11.63 & 0.91 & 2.74 & 1.04 & 50.59 & 40.65 & 6.27 & 0.52 & 1.70 & 0.26 \\
\hline
\end{tabular}

Explanation: $\quad \mathrm{CC}=$ Complete $\quad$ Comprehension; $\quad \mathrm{PC}=$ Partial Comprehension; $\quad \mathrm{PM}=\mathrm{Partia}$ Misconception; $\mathrm{M}=$ Misconception; $\mathrm{NC}=$ No Comprehension, and $\mathrm{E}=$ Error.

Table 5 above shows that the majority of prospective primary school teachers $(60.39 \%)$ were still in the category of Partial Comprehension in understanding the topic of states of matter and their changes. The use of the POE strategy had succeeded in increasing the understanding of more than half $(50.59 \%)$ of them in the category of Complete Comprehension. However, there were still many prospective teachers in the PC category.

To obtain the significance of mean score differences between pretest and posttest on four levels of comprehension (macroscopic, verbal submicroscopic, visual submicroscopic, and symbolic), the mean difference test, the Wilcoxon-test and the $t$-test were conducted. The tests were conducted by using SPSS version 20.0, and its results are presented in Table 6.

Table 6

Summary of Paired Sample

\begin{tabular}{|c|c|c|c|c|c|c|c|}
\hline Pair & Level & Score & $\mathrm{N}$ & Mean & SD & $\begin{array}{l}\text { Asymp. } \\
\text { Sig. (2- } \\
\text { tailed) } \\
\text { Wilcoxon- } \\
\text { test }\end{array}$ & $\begin{array}{l}\text { Sig. } \\
(2- \\
\text { tailed) } \\
\text { t-test }\end{array}$ \\
\hline \multirow{2}{*}{ Pair 1} & \multirow{2}{*}{ Macroscopic } & Pretest & 45 & 75.5564 & 13.21122 & \multirow{2}{*}{.000} & \multirow{2}{*}{ - } \\
\hline & & Posttest & 45 & 83.5309 & 8.92220 & & \\
\hline \multirow{2}{*}{ Pair 1} & Verbal & Pretest & 45 & 64.3140 & 18.27867 & \multirow{2}{*}{ - } & \multirow{2}{*}{.000} \\
\hline & submicroscopic & Posttest & 45 & 79.7396 & 15.49060 & & \\
\hline \multirow{2}{*}{ Pair 1} & Visual & Pretest & 45 & 58.3009 & 15.60513 & \multirow{2}{*}{ - } & \multirow{2}{*}{.000} \\
\hline & submicroscopic & Posttest & 45 & 78.5629 & 16.11739 & & \\
\hline \multirow{2}{*}{ Pair 1} & \multirow{2}{*}{ Symbolic } & Pretest & 45 & 59.0853 & 18.42968 & \multirow{2}{*}{ - } & \multirow{2}{*}{.000} \\
\hline & & Posttest & 45 & 76.3407 & 14.10454 & & \\
\hline
\end{tabular}

International Journal of Instruction, July $2019 \bullet$ Vol.12, No.3 
Table 6 shows that the $p$-value was generally $<0.025$. Thus, $\mathrm{H}_{\mathrm{o}}$ was rejected and $\mathrm{H}_{1}$ was accepted. Therefore, it can be concluded that there was a significant difference in the prospective primary school teachers' comprehension on the states of matter and their changes topic at the macroscopic, verbal submicroscopic, visual submicroscopic, and symbolic levels before and after the use of the POE strategy. The posttest score mean was greater than the pretest score mean, indicating that the use of POE strategy could improve prospective primary school teachers' comprehension of the states of matter and their changes topic.

Furthermore, to establish the pattern of concept changes that occurred in the prospective primary school teachers', their answers were grouped based on the concept change pattern of each category of answers in the pretest and posttest. The emerged pattern is summarized in Table 7.

Table 7

Percentage of Conception Changes Pattern in Prospective Primary School Teachers

\begin{tabular}{|c|c|c|c|c|c|c|c|}
\hline \multirow[b]{2}{*}{ Pretest } & \multicolumn{6}{|l|}{ Posttest } & \multirow{2}{*}{ Sum } \\
\hline & $\mathrm{CC}$ & PC & PM & $\mathrm{NC}$ & $\mathrm{M}$ & $\mathrm{E}$ & \\
\hline $\mathrm{CC}$ & $17.12 *$ & 5.75 & 0.26 & 0 & 0.13 & 0.13 & 23.39 \\
\hline PC & 27.84 & $26.4 *$ & 4.18 & 0.39 & 1.18 & 0.13 & 60.26 \\
\hline PM & 4.18 & 5.75 & $1.18^{*}$ & 0.13 & 0.39 & 0 & 11.63 \\
\hline $\mathrm{NC}$ & 0.52 & 0.39 & 0 & 0 & 0 & 0 & 0.92 \\
\hline M & 0.78 & 1.44 & 0.52 & 0 & 0 & 0 & 2.75 \\
\hline E & 0.26 & 0.65 & 0.13 & 0 & 0 & 0 & 1.05 \\
\hline Sum & 50.72 & 40.52 & 6.27 & 0.52 & 1.70 & 0.26 & 100 \\
\hline
\end{tabular}

Explanation: $\quad \mathrm{CC}=$ Complete $\quad$ Comprehension; $\quad \mathrm{PC}=$ Partial $\quad$ Comprehension; $\mathrm{PM}=$ Partial Misconception; $\mathrm{M}=$ Misconception; $\mathrm{NC}=$ No Comprehension, and $\mathrm{E}=$ Error.

*Does not experience changes in conception.

Table 7 shows that more than half of the prospective teachers $(55.16 \%)$ experienced a change in conception. No change in conception was found to be $44.84 \%$ (CC-CC: 17.12\%; PC-PC: 26.54\%; PM-PM: 1.18\%). Overall, there were 24 patterns of conception change. The PC-CC pattern ranked first from the concept change pattern on the existing answers, meaning that prospective primary school teachers tended to change their concepts to a better and more scientific direction. The third rank was the CC-CC pattern. This suggested that students studying using POE strategy were more likely to retain their concepts that are in line with scientific concepts.

\section{DISCUSSION}

The posttest and pretest meansof prospective primary school teachers' comprehension at the macroscopic, the verbal submicroscopic, the visual submicroscopic, and the symbolic levels varied. Comprehension at the macroscopic level (for all questions or sub-materials) has a greater percentage than the other levels. Meanwhile, the percentage of comprehension at the symbolic level is smaller than the other levels. The results of this study are in line with previous research (Sopandi et al., 2017; Banawi et al., 2017).

The results of the aforementioned descriptive analysis were further clarified with the results of the inferential statistical test. The results of statistical tests showed that 
prospective teachers' comprehension before and after the use of the POE strategy was different. There was an increase in the mean score of prospective teachers' comprehension of states of matter and their changes at all levels.

Table 3 illustrates that prior learning experiences had not provided adequate comprehension for the prospective primary school teachers to help their students learn about states of matter and their changes (Sopandi et al., 2017). Therefore, they need to improve their comprehension of prerequisite concepts. The prerequisite concepts for states of matter and their changes on discontinuity of matter and dynamic property of particles will help the prospective teachers to comprehend the topic. This is in line with previous research (Sopandi et al., 2018) indicating that students' good comprehension of discontinuity of matter can help them to understand the states of matter and their changes at the submicroscopic level. It is expected that by understanding the discontinuity of matter and the dynamic properties of particles, prospective teachers can apply that understanding to various concepts and other related representations. A significant factor in the effective use of explanations by learners was their ability to recognize various forms of representations of science phenomena and to transfer from one level of representation to another (e.g., submicroscopic to macroscopic, symbolic to submicroscopic) (Treagust et al., 2003).

The percentage of comprehension at the symbolic level was smaller than the other levels (Table 4). Nevertheless, the posttest mean score at that level was 76.34 (see Table 6). This indicated that learning outcomes at these levels were sufficient. Therefore, no more effort was needed to improve learning outcomes at this level. Mastery of a simple symbolic level, such as a symbol of an element or a symbol of existence, can be obtained by memorization. Simple chemical symbols and molecular formulas can also be obtained by memorization (Taber, 2009).

In addition, the teachers should pay attention to the submicroscopic level (verbal and visual) since it could serve as a bridge between the macroscopic level and the symbolic level. To help introducing this level, a media like computer(Sopandi et al., 2018) is needed to help the prospective teachers understand submicroscopic level. Hence, the use of learning technology in the course is very necessary.

The use of POE strategy had succeeded in improving more than half of the prospective teachers' comprehension in the $\mathrm{CC}$ category. However, there were still many prospective teachers in the PC category (see Table 5). Therefore, lecturers should do their best to teach the concept by minimizing errors and distortions. In other words, concepts are always correct (Ibrahim, 2012, p.18). The results of this study are consistent with previous researches that POE strategies can improve mastery of students' concepts (Cos stu, Ayas \& Niaz, 2012; Cinici \& Demir, 2013; Kibirige, Osodo \& Tlala, 2014). This strategy is perceived as good for increasing students' understanding (Liew \& Treagust, 2004; Adebayo \& Olufunke, 2015; Teo, Yan \& Goh, 2016; Sreerekha, Arun \& Swapna, 2016) and can correct the misconceptions of prospective teachers and teachers (Ipek et al., 2010). Although it can improve the ability of students, using POE may appear as a slow way of teaching (Mthembu, 2001). Therefore, it takes a long time to have conceptual change. 
Based on the results of the descriptive and inferential analyses (Table 6), it can be concluded that the prospective teachers' comprehension on states of matter and their changes at macroscopic, verbal submicroscopic, visual submicroscopic, and symbolic levels could be influenced by the instruction or the delivery of the learning materials. This proves the opinion that the instructional effect and nurturant effect is always inherent in the learning process and the proportion, when properly regulated, can facilitate the realization of the desired goals (Banawi, 2009).

Table 7 illustrates the tendency of a shift of Complete Concept Comprehension category from the pretest to the posttest. This showed that the change in student conception wasin a positive direction. In other words, students tended to change their conception in accordance with existing scientific concepts once they learned using POE strategy.

The results of this study can be used as diagnostic data (groups and individuals) to be considered in order to develop actions for improving learning. Individual learners diagnostic data illustrated the strengths and weaknesses of each individual learner. (Duskri et al., 2014). The results of the diagnosis were very helpful for educators in planning and implementing remedial teaching on materials that have not been mastered by learners. Lecturers, for example, can provide feedback by repeating the questions in the five-tier diagnostic test when giving lectures. Feedback by repeating questions is an easy way to find out student mistakes (Cengiz \& Ayvaci, 2017). Before the prospective teachers study in the classroom, they can be assigned to write predictions of an experiment in the form of a Student Individual Prediction Form (SIPF) or an initial worksheet as part of the predict stage. They can be asked to predict what will happen and provide reasons for their prediction of the experiment or a scientific phenomenon. Asking question in pre-learning activity before students learn certain materials formally in the class is indicated to improve students' learning readiness (Sopandi \& Sutinah, 2016; Sopandi \& Iswara, 2017; Sopandi, 2017a).

From the test results (with the five-tier diagnostic test), the patterns of concept changes of prospective primary school teacher were identified. The results of this study showed that there were still misconceptions about states of matter and their changes. This finding is in line with previous findings that showed' Nature of Particle Substance' is one of the concepts in which learners have the most alternative concepts (Bilgin et al., 2017; Sopandi, 2017b; Sopandi et al., 2018). Correspondingly, conception change is not an easy task and misconceptions are difficult to correct (Barke et al., 2009; Suparno, 2013: 7; Setyaningrum, 2016). Nevertheless, prospective teachers' misconceptions need to be studied and the reflective solutions need to be found by lecturers in order to achieve the learning objectives, since misconceptions can impede students from achieving learning goals (Kadarohman et al., 2010; Fariyani et al., 2015; Alfiani, 2015).

\section{CONCLUSION}

Based on the results of this study, it can be concluded that the previous learning experience had not been enough to equip prospective primary school teachers' comprehension to help them learn about the topic of states of matter and their changes. To address this issue, the POE strategy was used to improve prospective primary school 
teachers' comprehension. However, the improvement was still in the medium category. Comprehension at the macroscopic level (for all questions and sub-materials) had a greater percentage than the other levels (verbal submicroscopic, visual submicroscopic, and symbolic levels). Meanwhile, the percentage of comprehension at the symbolic level percentage was smaller than other levels. The use of POE strategies had succeeded in improving the comprehension of more than half $(50.59 \%)$ prospective teachers'in the CC category. However, there were still many students in the PC category. Their comprehension on the states of matter and their changes topic at the macroscopic, verbal submicroscopic, visual submicroscopic, and symbolic levels before and after the use of the POE strategy were different. They tended to change their conception in accordance with existing scientific concepts after they learned with the POE strategy.

The results of this study have several implications for classroom practice. Improvement of the lecture and the instruments used are absolutely necessary. Improvement of lecture process is directed towards what lecturers should do in the classroom so that the students' comprehension can be improved from medium category to high category.The improvement of a lecture can be done by using technology in the lecture. As for the instructional documents (syllabus or lesson plan, student worksheet, Conceptual Change Text (CCT) reading materials, and problem items) used in the classroom, improvements are necessary according to needs by emphasizing the students' lack of comprehension on sub-materialsand certain levels of understanding. Additionally, to improve the efficiency of the teaching materials used in the classroom, distributing existing materials to the students can be done before the lecture begins (Sopandi \& Iswara, 2017).

Another implication of this study is the need for further study with a broader subject to determine the effectiveness of using POE strategy on the topic of states of matter and their changes.

\section{ACKNOWLEDGMENTS}

The author would like to thank the Directorate General of Islamic Higher Education of the Ministry of Religious Affairs of Republic of Indonesia as the sponsor of the Morascholarship 2015 in supporting the first author's finance, and to the Primary School Teacher Education Study Program, School of Postgraduate Studies, Universitas Pendidikan Indonesia who has supported the authors' participation in this journal.

\section{REFERENCES}

Adebayo, F., \& Olufunke, B. T. (2015). Generative and predict-observe-explain instructional strategies: towards enhancing basic science practical skills of lower primary school pupils. International Journal of Elementary Education, 4(4), 86-92.

Alfiani. (2015). Analisis profil miskonsepsi dan konsistensi konsepsi siswa SMA pada topik suhu dan kalor. Prosiding Seminar Nasional Fisika 2015 Jakarta-Indonesia (pp. 29-32). Jakarta: Jurusan Fisika Fakultas MIPA Universitas Negeri Jakarta.

Banawi, A. (2009). Penanaman nilai-nilai budi pekerti melalui pembelajaran konsep cahaya pada siswa Sekolah Dasar. Jurnal Inovasi, 11: 19-32. 
Banawi, A., Sopandi, W., Kadarohman, A., \& Solehuddin, M. (2017). Pemahaman wujud zat dan perubahannya mahasiswa calon guru dan solusi reflektif: Studi pada salah satu perguruan tinggi di Maluku. Jurnal Inovasi, 11(2), 147-156.

Banawi, A., Sopandi, W., Kadarohman, A., \& Solehuddin, M. (2018). The development of a five-tier multiple-choice diagnostics tests to identify prospective primary school teacher' misconceptions about states of matter and their changes. Proceedings International Conference on Social Science and Technology in Education (ICSATE 2018) Ambon-Indonesia (pp. 1-10). Ambon: FITK IAIN Ambon.

Barke, H. D., Al Hazari, Al., \& Yitbarek, S. (2009). Misconceptions in chemistry, Addressing perceptions in chemical education. Berlin Heidelberg: Springer-Verlag.

Bilgin, A. K., Yürükel, F. N. D., \& Yiğit, N. (2017). The effect of a developed react strategy on the conceptual understanding of students: Particulate nature of matter. Journal of Turkish Science Education, 14(2), 65-81.

Cengiz, E., \& Ayvaci, H. Ş. (2017). Analysing the feedback that secondary school science teachers provide for student errors that show up in their lessons. Journal of Turkish Science Education, 14, 109-124.

Cinici, A. \& Demir, Y. (2013). Teaching through cooperative POE tasks: a path to conceptual change. The Clearing House, 86: 1-10.

Cos,tu, B., Ayas, A., \& Niaz, M. (2012). Investigating the effectiveness of a poe-based teaching activity on students' understanding of condensation. InstrSci, 40, 47-67.

Creswell, J. W. (2016). Research design: pendekatan kualitatif, kuantitatif, dan mixed. (Terjemahan Achmad Fawaid). California: Thousand Oaks. (Originally published in 2009).

Duskri, M., Kumaidi, \& Suryanto. (2014). Pengembangan tes diagnostik kesulitan belajar matematikadi SD. Jurnal Penelitian dan Evaluasi Pendidikan, 18(1), 44-56.

Fariyani, Q., Rusilowati, A., \& Sugianto. (2015). Pengembangan four-tier diagnostic test untuk mengungkap miskonsepsi fisika siswa SMA kelas x. Journal of Innovative Science Education, 4(2), 41-49.

Gernale, J. P., Arañes, F. Q., \& Duad, V. (2015). The effects of predict-observe-explain (poe) approach on students' achievement and attitudes towards science.The Normal Lights, 9(2), 1-23.

Hakim, A., Liliasari, \& Kadarohman, A. (2012). Student concept understanding of natural products chemistry in primary and secondary metabolites using the data collecting technique of modified cri. International Online Journal of Educational Sciences, 4, 544-553.

Hasan, S.; Bagayoko, D. \& Kelley, EL. (1999). Misconceptions and the certainty of response index (cri). Phys. Educ, 34. 
Hilario, J. S. (2015). The use of predict-observe-explain-explore (POEE) as a new teaching strategy in general chemistry-laboratory. International Journal of Education and Research, 3(2), 37-48.

Ibrahim, M. (2012). Seri pembelajaran inovatif: Konsep, miskonsepsi dan cara pembelajarannya. Surabaya: Unesa University Press.

Ipek, H., Kala, N., Yaman, F., \& Ayas, A. (2010). Using POE strategy to investigate student teachers' understanding about the effect of substance type on solubility. Procedia Social and Behavioral Sciences, 2, 648-653.

Jaelani. (2015). Deskripsi pemahaman sains guru madrasah ibtidaiyah pada diklat teknis substantif peningkatan kompetensi metodologi pembelajaran di kankemenag kota kediri tahun 2015. Jurnal Inovasi, 9(3), 273-277.

Johnstone, A. H. (1982). Macro-and micro-chemistry. School Science Review, 64, 377379.

Johnstone, A. H. (2000). Chemical education research: Where from Here? Chemistry Education, 4, 34-48.

Joyce, C. (2006). Predict, observe, explain (POE). Accessed from https://arbs.nzcer.org.nz/strategies/poe.php.

Kadarohman, A.; Nahadi, \& Mira, RAM. (2010). Miskonsepsi dan sikap siswa pada pembelajaran lemak melalui praktikum pembuatan sabun transparan. Jurnal Pengajaran MIPA, 15/1, 45-49.

Karagöl, I. \& Bekmezci, S. (2015). Investigating academic achievements and critical thinking dispositions of teacher candidates. Journal of Education and Training Studies, 3(4), 86-92.

Keles, E., \& Demirel, P. (2010). A study towards correcting student misconceptions related to the color issue in light unit with POE technique. Procedia Social and Behavioral Sciences, 2, 3134-3139.

Kibirige, I., Osodo, J., \& Tlala, K. M. (2014). The effect of predict-observe-explain strategy on learners' misconceptions about dissolved salts. Mediterranean Journal of Social Sciences, 5(4), 300-310.

Lating, AD. (2014). Belajar dengan strategi kognitif dalam konteks psikologi perkembangan. Horizon Pendidikan, 9(1), 1-12.

Li, W. S. S., \& Arshad, M. Y. (2014). Application of multiple representation levels in redox reactions among tenth grade chemistry teachers. Journal of Turkish Science Education, 11, 35-52.

Liew, C. W., \& Treagust, D. (2004). The effectiveness predict - observe - explain (POE) technique in diagnosing student's understanding of science and identifying their level of achievement [Electronic version]. 
Mancuso, V. J. (2010). Using discrepant events in science demonstrations to promote student engagement in scientific investigations: an action research study. (Disertation). Warner School of Education and Human Development, University of Rochester, New York.

Meltzer, D. E. (2002). The relationship between mathematics preparation and conceptual learning gains in physics: A possible hidden variable: in diagnostic pretest scores. American Association of Physics Teachers, 70/12, 1259-1268.

Mthembu, Z. (2001). Using the predict-observe-explain technique to enhance the students' understanding of chemical reactions (Short report on pilot study). Paper presented at the Australian Association for Research in Education (AARE) Annual Conference, Fremantle, 2001, pp. 1-11.

Sanjaya, W. (2009). Strategi pembelajaran berorientasi proses pendidikan. Bandung: Kencana Prenada Media Group.

Setyaningrum, V. (2016). Perubahan konseptual siswa smp pada materi suhu dan kalor melalui teks perubahan konseptual berbasis kartun konsep. (Thesis). Sekolah Pascasarjana, Universitas Pendidikan Indonesia, Bandung.

Sopandi, W., \& Iswara, P. D. (2017). Pengajuan pertanyaan pra-pembelajaran dalam model pembelajaran RADEC untuk meningkatkan keterampilan membaca pemahaman peserta didik. Proceeding 2nd international Multiliteracy Conference and Workshop for Students and Teachers (pp. 405-420). Bandung: Graduate School, UPI.

Sopandi, W., \& Sutinah, C. (2016). Optimize the increase of students' conceptual understanding by learning at the zone of proximal development. Proceedings International Seminar on Science Education (pp. 1-7). Yogyakarta: Graduate School, Yogyakarta State University.

Sopandi, W. (2017a). The quality improvement of learning processes and achievements through the read-answer-discuss-explain-and create learning model implementation. Proceeding 8th Pedagogy International Seminar 2017: Enhancement of Pedagogy in Cultural Diversity Toward Excellence in Education (pp. 132-139). Kualalumpur, Malaysia.

Sopandi, W. (2017b). Pengenalan sifat diskontinu materi pada peserta didik sekolah dasar kelas tinggi sebagai dasar belajar kimia. Dalam U. S. Saud, W. Sopandi \& H. Handayani (Editor), Bunga Rampai Kajian Pendidikan Dasar: Umum, Matematika, Bahasa, Sosial, dan Sains (pp. 161-173). Bandung: UPI Press.

Sopandi, W., Kadarohman, A., Rosbiono, M., Latip, A., \& Sukardi, R. R. (2018) The courseware of discontinuous nature of matter in teaching the states of matter and their changes. International Journal of Instruction, 11, 61-76.

Sopandi, W., Latip, A. \& Sujana, A. (2017). Prospective primary school teachers' understanding on states of matter and their changes. Journal of Physics, Conf. Series $812,1-8$. 
Sreerekha, S., Arun, R. R., \& Swapna, S. (2016). Effect of predict-observe-explain strategy on achievement in chemistry of secondary school students. International Journal of Education \& Teaching Analytics, 1(1), 1-5.

Sugiyono. (2013). Metode penelitian pendidikan: pendekatan kuantitatif, kualitatif, dan $R \& D$. Thirdedition. Bandung: Alfabeta.

Suparno, P. (2013). Miskonsepsi dan perubahan konsep dalam pendidikan fisika. Jakarta: Grasindo.

Taber, K. S. (2009). Learning at the symbolic level. Multiple representations in chemical education. Models and Modelling in Science Education, 4, 75-105.

Teo, T.W., Yan, Y.K., \& Goh, M. T. (2016). Using prediction-observation-explanationrevision to structure young children'slearning about floating and sinking. The Journal of Emergent Science, JES, 10, 12-23.

Treagust, D., Chittleborough, G. \& Mamiala, T. (2003). The role of submicroscopic and symbolic representations in chemical explanations. International Journal of Science Education, 25(11), 1353-1368. 